\title{
脱镁叶绿酸的硝(烃基)化反应及其叶绿素类二氢卟吩衍生物的合成
}

\author{
张 珠 ${ }^{a}$ \\ 李家柱 ${ }^{b}$ 王欣悦 ${ }^{b}$ \\ 马计划 ${ }^{b}$ 王 旭 ${ }^{b}$ \\ 王进军*, $a, b$

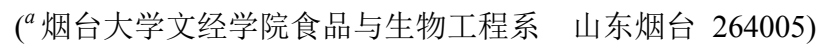 \\ $\left(^{b}\right.$ 烟台大学化学化工学院 山东烟台 264005)
}

\begin{abstract}
摘要 以脱镁叶绿酸-a 甲酯为起始原料, 利用其周环上的活性反应基团进行化学修饰, 在 $N^{21}-N^{23}$ 轴向两端构建了甲酰 基、烯酮和邻位二酮结构, 通过芳香性大环色基的亲电取代、活性兼基的 Henry 反应以及外接环上作为不同给受体的 $\beta$-酮酯和烯酮的 Michael 加成, 分别在 3-、12-、20-位和外接环上实施硝化和硝烃基化, 完成了一系列未见报道的硝(烷) 基取代的叶绿素类二氢卟吩衍生物的合成, 其化学结构均经 UV-Vis、IR、 ${ }^{1} \mathrm{H}$ NMR 及元素分析予以证实. 关键词 叶绿素; 脱镁叶绿酸, 二氢卟吩; 硝(烷基)化反应; 合成
\end{abstract}

\section{Nitration (Nitroalkylation) of Pheophorbide and Synthesis of Chlorophyllous Chlorin Derivatives}

\author{
Zhang, Zhu ${ }^{a} \quad \mathrm{Li}$, Jiazhu ${ }^{b} \quad$ Wang, Xinyue $^{b} \quad$ Ma, Jihua $^{b} \quad$ Wang, Xu $^{b} \quad$ Wang, Jinjun ${ }^{*, a, b}$ \\ ( ${ }^{a}$ Department of Food \& Biological Engineering, Wenjing College, Yantai University, Yantai, Shandong 264005) \\ $\left({ }^{b}\right.$ College of chemistry and chemical engineering, Yantai University, Yantai, Shandong 264005)
}

\begin{abstract}
Pyropheophorbide-a methyl ester was used as a starting material, and the chemical modification was carried out making use of its active groups attached to the chlorin periphery to establish the formyl group, ketene and $\alpha$-diketone moieties around the $N^{21}-N^{23}$ axis. The nitrations or nitroalkylations at 3-, 12-, 20-position and on the exocyclic ring were performed by the electrophilic substitution on the aromatic macrocyclic chromophore, Henry reaction at the active carbonyl groups, and Michael addition to the $\beta$-keto ester and the ketene structures on the exocyclic ring as different donor-acceptor. A series of unreported nitro(nitroalkyl) substituted chlorins related to chlorophyll were synthesized and their chemical structures were characterized by elemental analysis, UV-Vis, IR and ${ }^{1} \mathrm{H}$ NMR spectra.

Keywords chlorophyll; pheophorbide; chlorin; nitration(nitroalkylation) reaction; synthesis
\end{abstract}

\section{Introduction}

Chlorophylls (Chls) are known to play important roles in light absorption and energy/electron transfer in natural photosynthesis. These excellent photofunctional abilities depend on their multi-level $\pi$-systems in the chromophore and the substituted groups along the periphery. From many quantitative structure-activity relationship (QSAR) studies it has been shown that the presence, variety and position of the substituents in the parent molecule of chlorophyll made a remarkable difference in photophysical and photobiological activity. ${ }^{[1-2]}$ Chlorophyll-a derivatives had also been applied as photosensitizers in various areas, such as artificial photosynthetic reaction centers, dye-sensitized solar cells, photodynamic therapy (PDT) and sensor devices..$^{[3-5]}$ Therefore, establishing special functional groups around the porphyrin core has become an important strategy to produce useful tetrapyrrolic macrocycle compounds. ${ }^{[6-8]}$

Among these modifications for chlorophyll, the introduction of nitro group is a highly valued functionalization due to its triangular conjugated planar structure and strong electron-withdrawing capacity which may effectively influence and alter the basic properties of chlorins, such as electronic absorption spectrum, redox potential and S1energy. In addition, the reduction of nitro group is a main access to amino group as one of the most important functional units in organic synthesis. The nitrification for porphyrin has also been attracted wide attention and many

\footnotetext{
* Corresponding authors. E-mail: wjj1955@163.com

Received April 30, 2020; revised May 31, 2020; published online June 11, 2020.

Project supported by the National Natural Science Foundations of China (No. 21272048) and the Natural Science Foundation of Shandong Province (No. ZR2015BQ012).
}

国家自然科学基金(No. 21272048)和山东省自然科学基金(No. ZR2015BQ012)资助项目. 
nitroporphyrins have demonstrated various unique properties and good application prospects. ${ }^{[9-10]}$ However, relevant reports related to chlorophyllous chlorin are scarce except our early papers and other's in which nitro group was introduced at 3- and 20-position, respectively. ${ }^{[11]}$ As a part of our research program, we report the synthesis of nitro-linked chlorins related to chlorophyll by introducing nitro group at 3-, 12-, 20- and on exocyclic ring (E-ring) based on classic chemical reaction.

In our approach, methyl pheophorbide-a (MPa, 1), prepared from accessiable Spirulina pacifica, ${ }^{[12]}$ was used as starting material for the synthesis of nitryl-containing chlorophyll derivatives. Firstly, methyl pheophorbide-d (MPd, 2) attaching a formyl group at 3-position was prepared by a one-pot reaction comprising an oxidation with osmium(VIII) oxide and the glycol cleavage with sodium periodate. The Henry reaction of this aldehyde with nitromethane proceeded favorably in dichloromethane with TEA to afford chlorin nitro-alcohol $\mathbf{3}$ in excellent isolated yield, and subsequent dehydration was carried out initially in refluxing toluene using $\mathrm{TsOH}$ as catalyst to give de-esterified 3b-nitropyropheophorbide-a 4 in poor yield (4\%). This Henry product 3 was refluxed in TEA, instead of acid medium, to generate chlorin 4 in $29 \%$ yield. The nitration of $\mathrm{MPa} 1$ with mixed acid nitrating agent regioselectively introduced a nitro group at 20-meso-position. ${ }^{[6]}$ The newly formed nitrated chlorin 5 (56\%) converted smoothly to 20-nitropurpurin-18 $\mathbf{6}$ in excellent yield through allomerization, rearrangement and anhydridisation. The Michael addition of the $\beta$-ketoester moity in pheophorbide-a 1 with 1-(4-nitrophenyl)-2-nitrothene was performed in tetrahydrofuran (THF) containing $\mathrm{NaOCH}_{3}$ to attempting to introduce two nitro groups to the macrocycle in one step. However, the expected Michael product was so labile that it spontaneously converted to arylidene-substituted chlorin- $\mathrm{p}_{6} 7$ (31\%) and trance amounts of pyropheophorbide-a 8 during separation at room temperature, which both consisted of two inseparable $E / Z$-isomers (Scheme 1).

Based on the above reaction results, the constructions of active reaction regions can be considered as an imperative procedure to effectively introduce nitro group. In order to establish new function structures around the exocyclic ring, methyl pyropheophorbide-a (MPPa, 9), derived from MPa 1 by a deesterification in alkali medium, was chosen as a precursor. Its allomerization in the saturated methanol solution with $\mathrm{LiOH}$ exposed to air gave 12-formyl substituted chlorin 10 and $13^{2}$-oxo-chlorin 11 as two major oxidative products, respectively. ${ }^{[8 \mathrm{~b}]}$ The chlorin 12 with the enone moiety on the exocyclic ring also was synthesized in moderate yield by the aldol reaction of MPPa (9) with paraformaldehyde under an $\mathrm{N}_{2}$ atmosphere in the presence of sodium methoxide (Scheme 2).

Unlike MPd 2, the condensation of chlorin aldehyde $\mathbf{1 0}$ with nitromethane under the same condition directly generated dehydrated product $\mathbf{1 3}$ in $45 \%$ yield without finding the Henry product. Compared to formyl group, the Henry reaction of $\alpha$-diketo group on the E-ring required a relatively rigorous reaction condition due to its lower reactivity. The analogous nitro alkylation for chlorin diketo $\mathbf{1 1}$ using nitromethane as nitro source was carried out by refluxing in TEA to form 34\% nitromethylene substituted
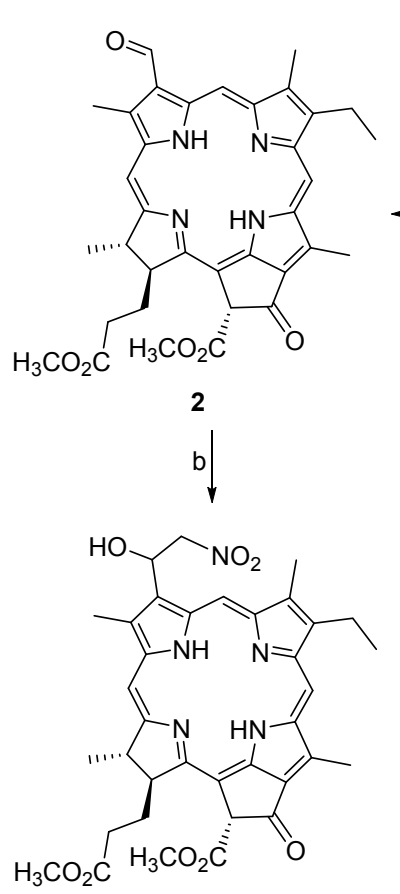

3

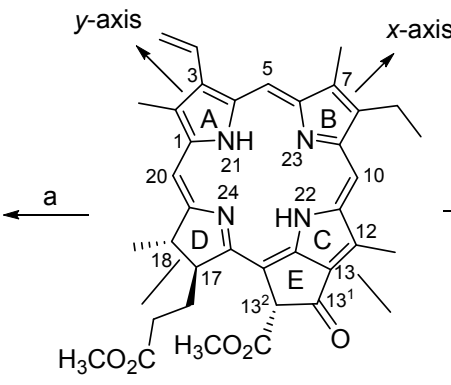

1
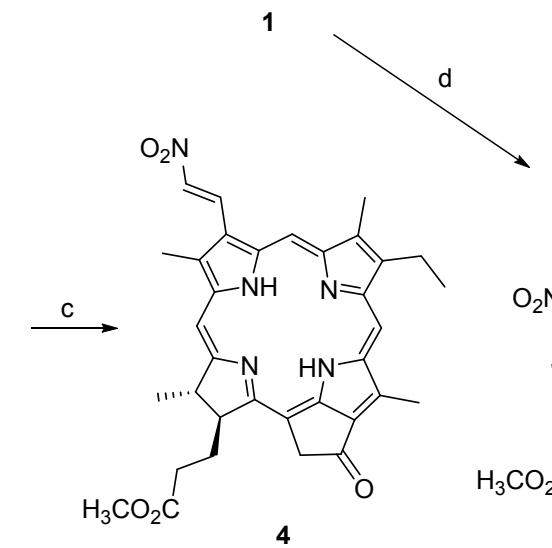
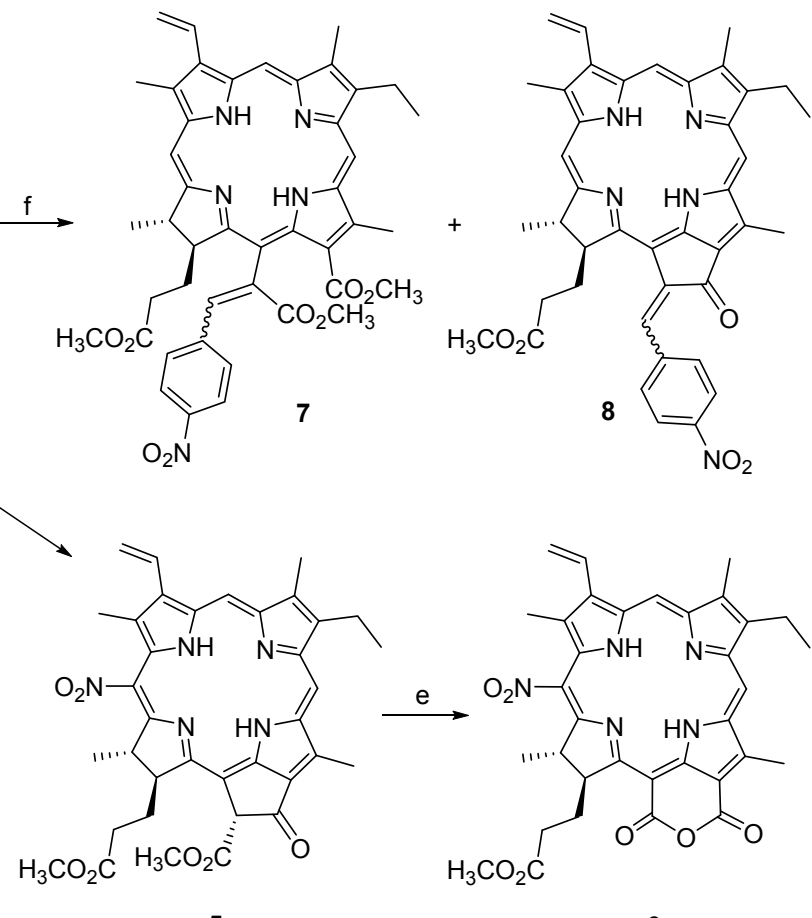

Reagents and conditions: (a) $\mathrm{OsO}_{4} / \mathrm{NaIO}_{4} / \mathrm{NaHSO}_{3}$; (b) $\mathrm{CH}_{3} \mathrm{NO}_{2} / \mathrm{TEA}$, r.t.; (c) TEA/reflux; (d) $\mathrm{HNO} / \mathrm{AcOH}$; (e) $\mathrm{KOH} / \mathrm{MeOH} / \mathrm{O}_{2}$; (f) $\mathrm{NaOCH}_{3} / \mathrm{THF} / p-\mathrm{O}_{2} \mathrm{NC}_{6} \mathrm{H}_{4} \mathrm{CH}=\mathrm{CHNO}_{2}$.

Scheme 1 Synthesis of nitro-substituted methyl pheophorbide-a derivatives at 3- and 20-positions 


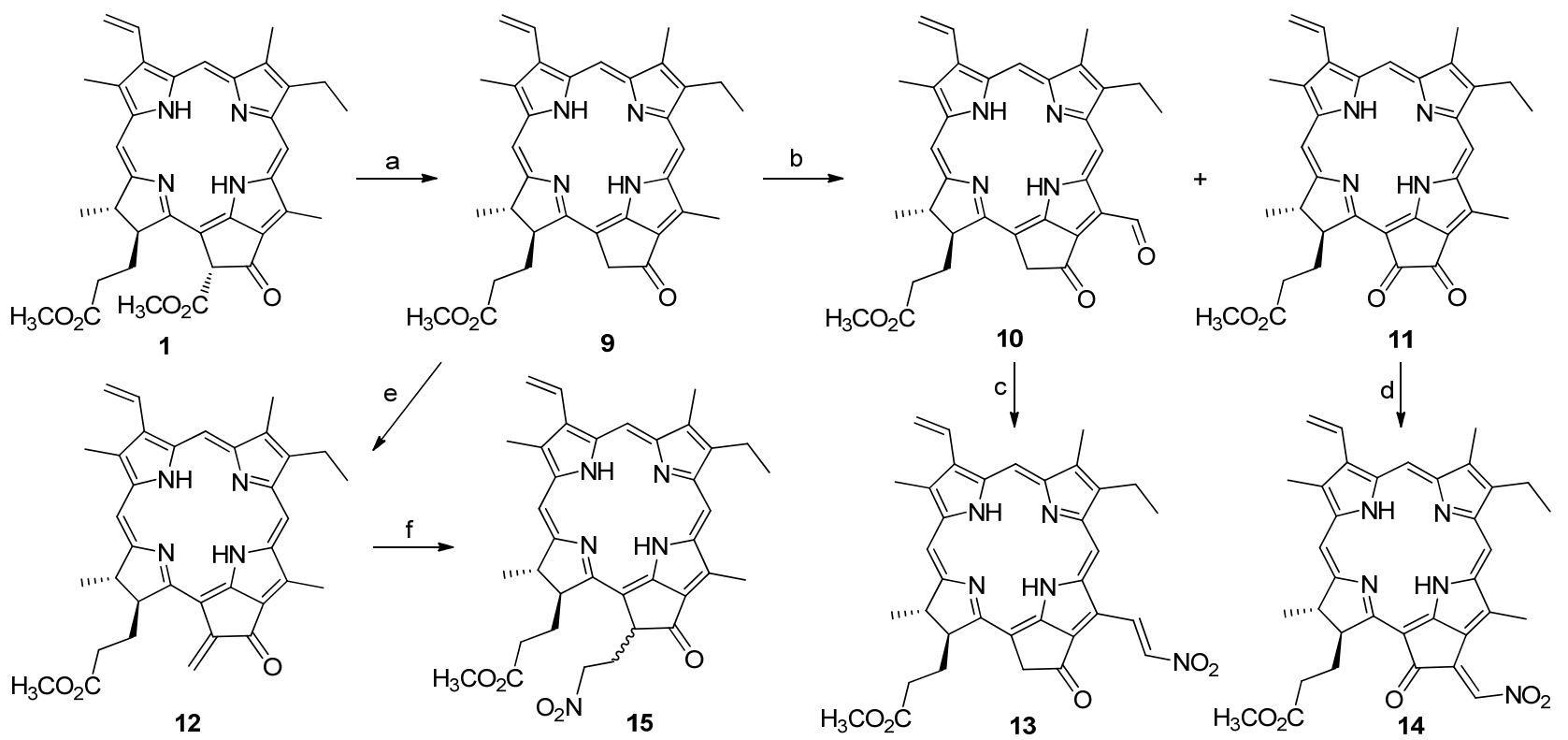

Reagents and conditions: (a) Pyr/ $\mathrm{H}_{2} \mathrm{O} /$ reflux; (b) $\mathrm{LiOH} / \mathrm{MeOH} / \mathrm{THF} / \mathrm{H}_{2} \mathrm{O} / \mathrm{O}_{2}$; (c) $\mathrm{CH}_{3} \mathrm{NO}_{2} / \mathrm{TEA}$, r.t.; (d) $\mathrm{CH}_{3} \mathrm{NO}_{3} / \mathrm{TEA} / \mathrm{reflux}$; (e) $\mathrm{CH}_{2} \mathrm{O} / \mathrm{NaOCH}_{3} / \mathrm{THF}$; (f) $\mathrm{CH}_{3} \mathrm{NO}_{2} / \mathrm{NaOCH}_{3}$

Scheme 2 Synthesis of nitro substituted methyl pheophorbide-a derivatives at 12-position and on the E-ring

chlorin 14 in one step. In contrast to MPa 1, the chlorin 12 as an electron acceptor could also react with nitromethane in THF using sodium methoxide as catalyst to afford nitroethylated Michael adduct $\mathbf{1 5}$ as a pair of epimers in 58\% yield (Scheme 2).

\section{Results and discussion}

2.1 Nitration (nitroalkylation) of pheophorbide based on the Hener reaction and Michael addition

The dehydration for Henry product 3 in refluxing toluene with $\mathrm{TsOH}$ was not processing smoothly and largely returned to MPd 2 with concomitant leaving of nitromethane via retro-Henry reaction. Under the acid condition (Path I in Figure 1), the sulfonate anion as Lewis base chiefly chose to captured the hydroxylic proton with stronger acidity, rather than the weakly acidic hydrogen atom at 3b-position, while in alkaline environment (Path II in Figure 1), like other $\beta$-nitro alcohols, ${ }^{[13]}$ a stable intramolecular hydrogen bond was formed between the 3a-hydroxyl and the 3b-nitro group and the hydroxylic hydrogen was wrapped in the middle, making it unavailable to touch with alkalic particle in the reaction system. Consequently, the dehydration reaction of the chlorin 3 was achieved through trans-elimination along the $\mathbf{3 a} \sim \mathbf{3} \mathbf{b}$ bond to give desired nitrovinyl-substituted chlorin 4 .

The Henry reactions of chlorin $\mathbf{1 0}$ and $\mathbf{1 1}$ did not separate relevant nitroalcohols $\mathbf{1 3 a}$ and $\mathbf{1 4 a}$, but rather their dehydrated products 13 and $\mathbf{1 4}$. The possible reason was that the interaction between their active protons attached to the carbon baring the nitro group with the adjacent carbonyl groups, analogous to hydroxylic hydrogen, weakened the bond energy of these $\mathrm{C}-\mathrm{H}$ bonds to some extent, thus facilitating the dehydration of the nitroalcohols to directly produce nitrovinyl-substituted chlorophyll derivatives

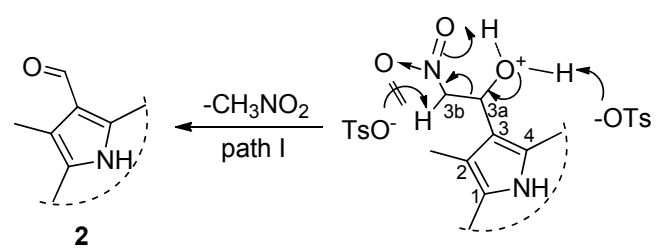

2

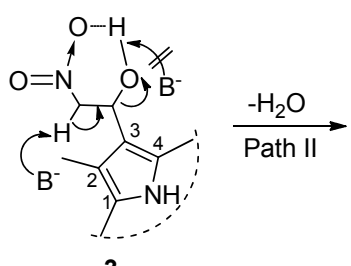

3
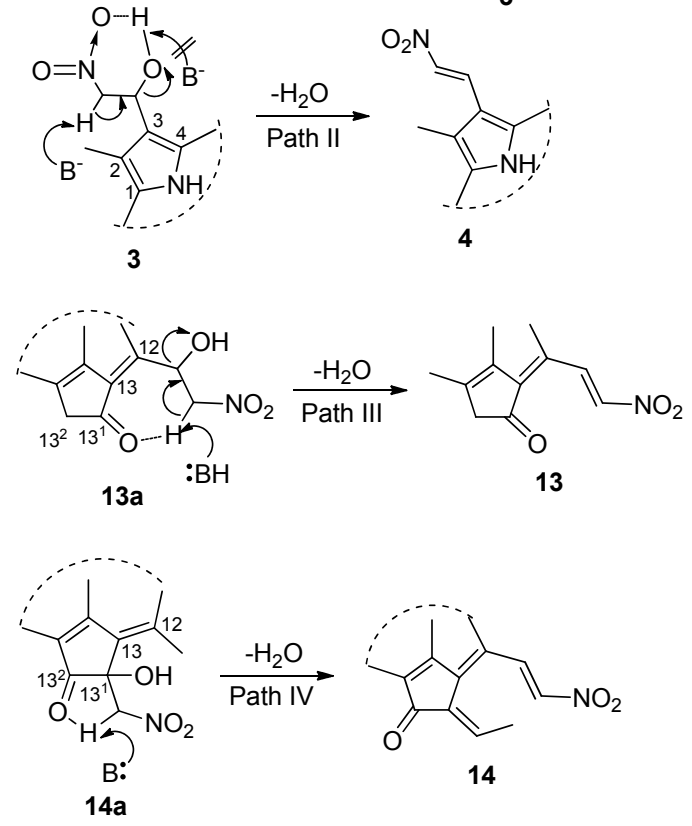

Figure 1 Dehydration reaction of different Henry reaction products

(paths III and IV in Figure 1).

The nucleophilic attack from both upper and lower faces in the Michael addition of chlorin ketene 12 with nitromenthane encountered different stereoscopic environment on the account of the asymmetry of chlorophyll molecule 
plan. The route-a approaching the E-ring from the opposite direction of the $\mathrm{C} 17$-propionic ester residue met with lesser steric hindrance to give the main epimer of chlorin 15 , but this conjugated addition along the route-b must overcome the repulsive interaction from the long chain substituted group at 17-position to generate another epimer as secondary product.

Analogously, the Michael addition of the MPa 1 with 1-aryl-2-nitroethylene started at the isomerization of the exocyclic ring and the formed enolic anion 1a as Michael donor could react with the electron acceptor from the both sides to produce epimers 7. The succedent nucleophilic additions to $\mathrm{C} 13^{2}$-ketone group and $\mathrm{C} 13^{1}$-methoxyformyl group, caused by methoxy anion in reaction system, formed tetrahedron intermediates $\mathbf{1 b}$ and $\mathbf{1 c}$ via the route-c and route-d, respectively. The former occurred ring opening reaction by eliminating a nitromethane to rearrange to $15 \mathrm{a}-(E / Z)$-arylidene-substituted chlorin- $e_{6} \mathbf{8}$, while the latter converted to $13^{2}-(E / Z)$-arylidene-substituted pyropheophorbide-a 9 with concomitant the leaving of nitromethane and dimethyl carbonate (Figure 2).

\subsection{Optical properties of pheophorbides possessing nitro(alkenyl) group at different positions}

All the UV-vis spectra give an intense band around 400 $\mathrm{nm}$, called a Soret band, and Qy bands appeared at a longest wavelength. The Qy band is accompanied with a weak vibrational band on the blue side. Between the Qy and Soret bands, less intense Qx bands are observed. The Qy and Qx bands are regulated by transition dipole moments along the molecular $y$ - and $x$-axes (Scheme 1), respectively, while the Soret band based on the By and Bx bands is controlled by both the dipole moments. Therefore, the Qy and Qx bands are largely dependent on substituents attached to A-, B- and C-ring, respectively, and the Soret band is dependent on all the three substituents.

For notroalkenylated chlorins $(4,13$ and 14$)$, the transformations from carbonyl to notroalkenyl group at the 3-, 12- and $13^{1}$-position all induced obvious red shifts of the redmost Qy maxima (Figure 3). However, these similar modifications brought about different shift ranges toward longer wavelength, namely, $\mathbf{2} \rightarrow \mathbf{4}(\Delta \mathrm{Qy}=8 \mathrm{~nm}), \mathbf{1 0} \rightarrow \mathbf{1 3}$ $(\Delta \mathrm{Qy}=15 \mathrm{~nm})$ and $\mathbf{1 1} \rightarrow \mathbf{1 4}(\Delta \mathrm{Qy}=19 \mathrm{~nm})$. In the conversion from $\mathrm{C}=\mathrm{C}$ to $\mathrm{C}=\mathrm{O}(\mathbf{9} \rightarrow \mathbf{2}, \mathbf{1 0 a} \rightarrow \mathbf{1 0}, \mathbf{1 1} \mathbf{b} \rightarrow \mathbf{1 1}),{ }^{[14]}$ the very different Qy maxmia of the oxidized chlorins are observed in the order of $\mathbf{9}(\Delta \mathrm{Qy}=26 \mathrm{~nm})>\mathbf{1 0}(\Delta \mathrm{Qy}=7$ $\mathrm{nm})>\mathbf{1 1}(\Delta \mathrm{Qy}=2 \mathrm{~nm})$. In terms of electronic effects, the same conjugated structures, attached to the end of the molecular $y$-axe, should have a similar impact on the extension of $\pi$-system of chromophore. But as far as spatial factor is concerned the differences between these reaction sites are evident. Therefore, the relevant effects of substituents on the visible spectra also are regulated by the surrounding stereo structures of the functional groups at 3-, 12- and $13^{1}$-positions (Figure 4).

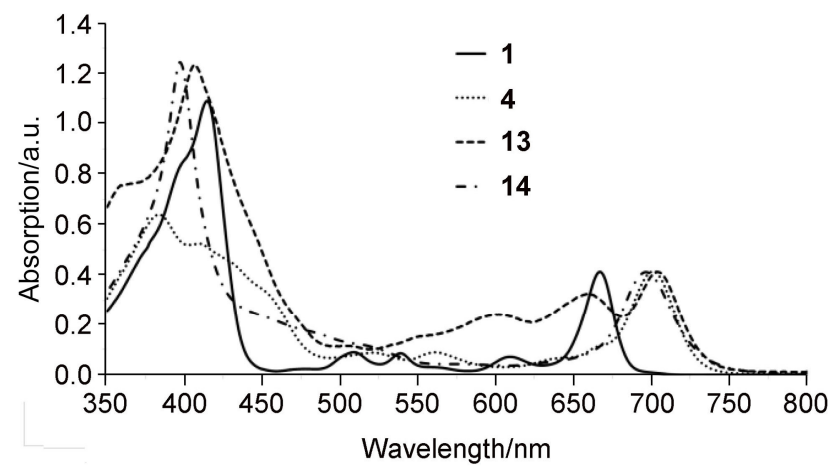

Figure 3 Comparative electronic absorption spectra of 1, 4, 13 and 14

All the spectra are normalized at Qy maxima

The conjugation of the $\mathrm{C}=\mathrm{O}$ double bond at 12- or $\mathrm{C} 13^{1}$-position with the chromophore encounters a steric hindrance from the adjacent carbonyl group. The nonbonding orbitals of the C12-formyl group of $\mathbf{1 0}$ are close to the ones of the E-ring carbonyl group. The mutual repulsion between them deflects the C12-formyl group away from the macrocyclic plane along the $\mathrm{C} 12-\mathrm{C} 12 \mathrm{a}$ bond axis and weakens their $\pi$-electron delocalization. The $\mathrm{C} 13^{1}$-carbonyl group in $\mathbf{1 1}$ endures a more crowded spatial

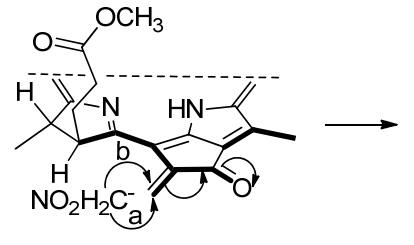

12

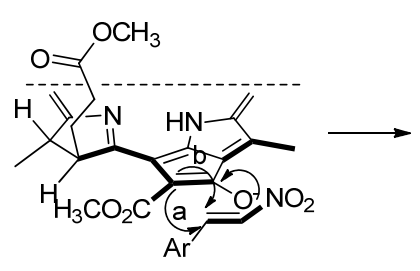

$1 \mathrm{a}$

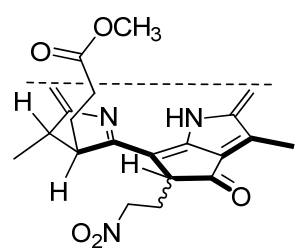

15

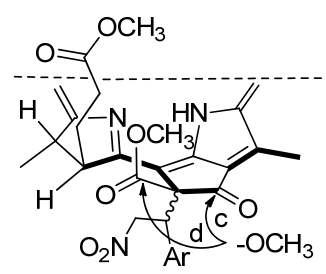

7

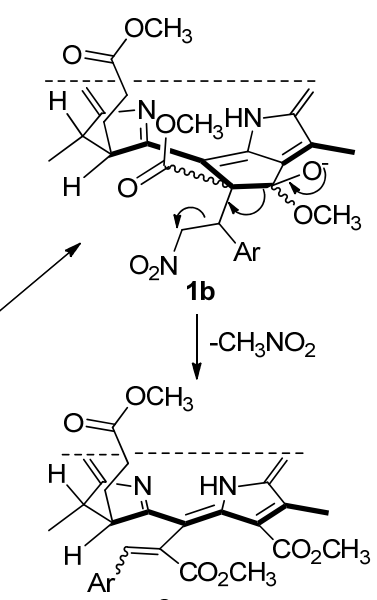

8

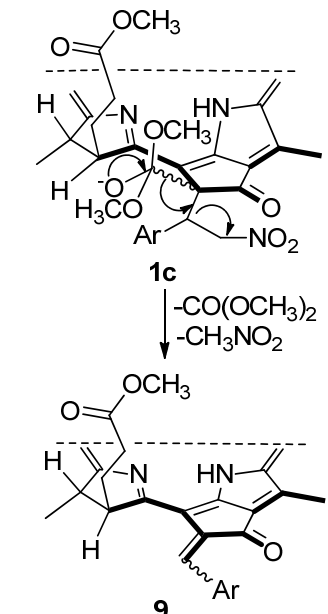

Figure 2 Forming process of nitroalkyl group on the exocyclic ring based on Michael addition 

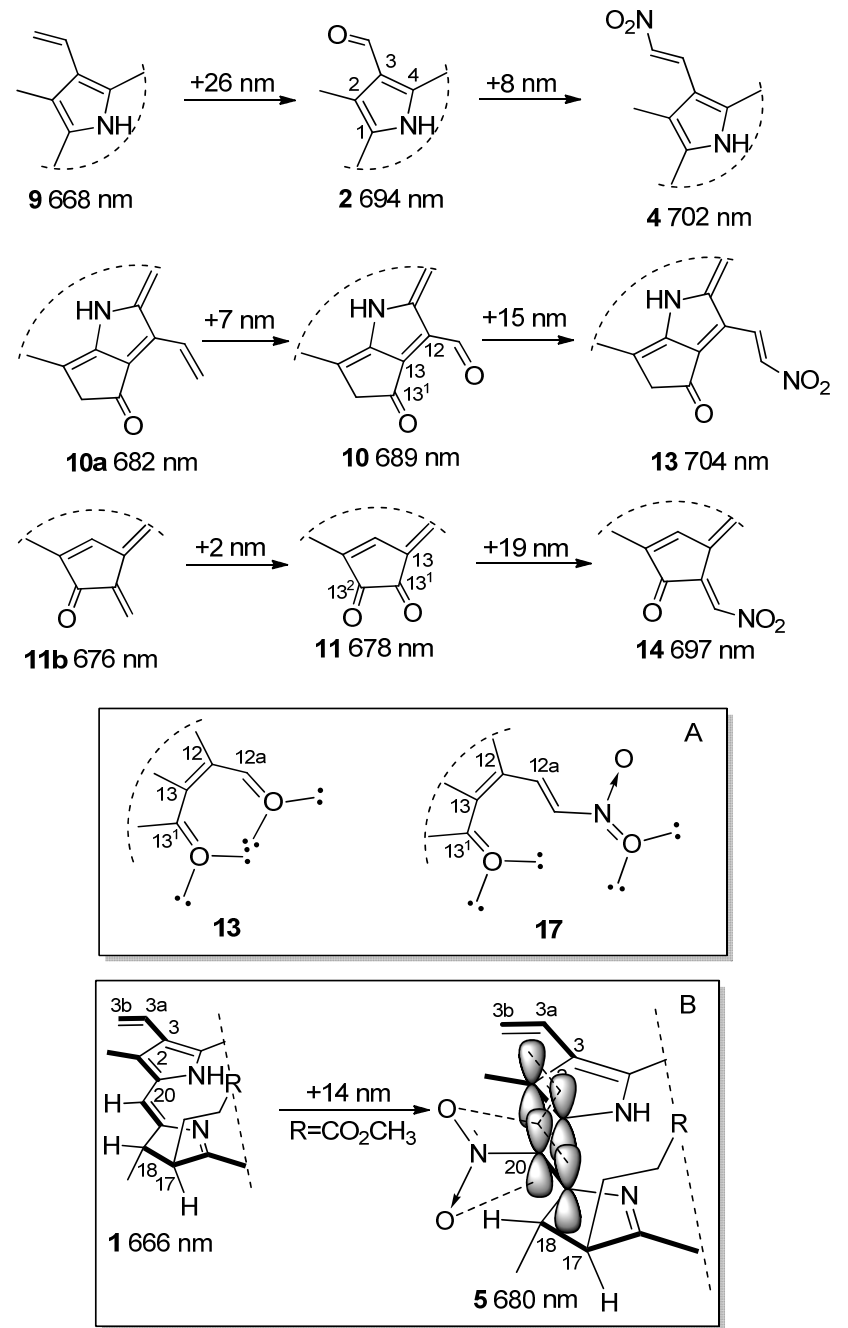

Figure 4 Substitutent effect on the Qy maxima at different positions on the chlorin periphery

environment, due to that it is located on the rigid exocyclic ring and adjacent to the keto-carbonyl group at $13^{2}$-position. The C3-formylation of chlorin 9, however, is not subjected to the influence from analogous steric hindrance, thus causing a significant red shift at the Qy band. On the contrary, the nitroalkenylations of chlorins $\mathbf{1 0}$ and $\mathbf{1 1}$ contribute to a large prolongation at their Qy maximum, comparing with same reaction for chlorin $\mathbf{2}$. Although the nitroalkenyl moiety is sterically bulkier than the correspond carbonyl group, the spatial repulsion between them is not increased but reduced due to the orientation of the nitro group which is away from other functional group (Figure $4 \mathrm{~A})$. The resulting increment of Qy maximum ( $\Delta$ Qy) benefits from the disappearance of the stereo repulsive force between the adjacent carbonyl groups, apart from the extension of $\pi$-conjugated system by establishing nitroalkenyl structure.

The 20-nitrochlorin 5 shows a red-shifted Qy absorption band at $680 \mathrm{~nm}$, moving to the red side for $14 \mathrm{~nm}(\Delta \mathrm{Qy})$ compared with MPa 1. However, the same nitrification at $3 \mathrm{~b}, 12 \mathrm{~b}$ and $13^{2} \mathrm{a}$-position bring about a more long-distance shift toward longer wavelength, namely, $\mathbf{9} \rightarrow \mathbf{4}(\Delta \mathrm{Qy}=34$ $\mathrm{nm}), \mathbf{1 0 a} \rightarrow \mathbf{1 3}(\Delta \mathrm{Qy}=23 \mathrm{~nm})$ and $\mathbf{1 1 b} \rightarrow \mathbf{1 4}(\Delta \mathrm{Qy}=21$ $\mathrm{nm})$. In fact, the plane of the C20-nitro group and the chlorin ring are perpendicular to each other, and its substitution effect on the Qy maxima is carried out by the hyperconjugation between the carbon-oxygen $\sigma$-bonds with the chromophore $\pi$-system (Figure 4B). In addition, the shift of Qy maxima dependent upon the 20 -substituent is primarily due to its factor steric. The sterically bulkier nitro group disturbs the chlorin $\pi$-plane and decreases the difference between HOMO and LUMO energy levels, ${ }^{[15]}$ leading to a bathochromic shift of the longest wavelength absorption band (Qy maxima).

\section{Conclusions}

The nitration and nitroalkylation of chlorins related to chlorophyll were accomplished making use of original active moieties and newly-established aldehyde or ketone group around the periphery based on electrophilic substitution, Michael addition and Henry reaction. The nitro group was introduced in different regions including at 3-, 12-, 20-position and on the exocyclic ring, respectively, to afford a series of unreported nitro-linked chlorophyll derivatives. The Soret and Q-absorption bands of the nitrated chlorins were closely related to the substituted sites of the nitro groups due to its triangular conjugated planar structure and strong electron-withdrawing capacity. These nitrations of chlorophyll derivatives and subsequent structural conversion of nitro group provided a more extensive synthetic route for acquiring novel tetrapyrrole macrocycle compounds with potential application prospect.

\section{Experimental section}

\subsection{General}

The UV-vis spectra were taken with a Unicam SP 800 spectrophotometer. The ${ }^{1} \mathrm{H}$ NMR spectra were recorded with a Varian 400 spectrometer. Mass spectra were recorded by a JMX-DX300 at eV. The elemental analyses were performed on a Perkin-Elmer 240 microanalyzer. Methyl pheophorbide-a (1) was obtained according to Smith's method. ${ }^{[12]}$ All chemical reagents were purchased from Merck, Fluka and Aldrich chemical companies and purified by using standard methods.

\subsection{Synthesis of methyl pheophorbide- $d$ (2)}

To a THF solution (15 mL) of MPa (1) (186 mg, 0.307 $\mathrm{mmol}), 0.5 \mathrm{~mL}$ of pyridine and osmium(VIII) oxide ( 85 $\mathrm{mg}, 0.334 \mathrm{mmol})$ in $2 \mathrm{~mL}$ of THF were added at $0{ }^{\circ} \mathrm{C}$, respectively. After stirring for $30 \mathrm{~min}$ at the same temperature, the reactive system was heated to room temperature and stirred for an additional hour. To the resultant mixture, an excess of a solution of sodium hydrogen sulfite $(15 \mathrm{~g})$ in $50 \% \mathrm{MeOH}$ was added and stirred for $20 \mathrm{~min}$. After filtering out the brown osmium(IV) oxide precipitate, $\mathrm{CH}_{2} \mathrm{Cl}_{2}$ $(20 \mathrm{~mL})$ and water $(20 \mathrm{~mL})$ were added to the mixture. The organic layer was separated and dried over anhydrous $\mathrm{Na}_{2} \mathrm{SO}_{4}$. The solvent was removed to give the solid mate- 
rial that was suspended in a mixture of THF $(15 \mathrm{~mL})$ and silica gel $(2.5 \mathrm{~g})$. On the treatment with a solution of sodium periodate $(1 \mathrm{~g})$ in water $(15 \mathrm{~mL})$, the color of the solution changed from green to bronze within $30 \mathrm{~min}$. After adding $\mathrm{CH}_{2} \mathrm{Cl}_{2}(20 \mathrm{~mL})$, the mixture was filtered through cotton wool and then the resultant crude material was chromatographed on silica gel with hexane-ethyl acetate $(V: V=3: 1)$ as eluent to give $161 \mathrm{mg}$ of $2(0.264$ mmol, $86 \%)$ as dark red solid. The analytical data were consistent with the ones in the literature. ${ }^{[16]}$

4.3 Synthesis of methyl 3(R/S)-3-(1'-hydroxyl-2'-nitroethyl)-3-devinylpheophorbide-a (3)

To a dichloromethane solution $(15 \mathrm{~mL})$ of MPd 2 (128 $\mathrm{mg}, 0.211 \mathrm{mmol})$, excess nitromethane $(3 \mathrm{~mL})$ and TEA $(2$ $\mathrm{mL}$ ) were added sequentially and stirred at room temperature under nitrogen atmosphere for $5 \mathrm{~h}$. The resultant mixture was poured into cool water and extracted with dichloromethane $(15 \mathrm{~mL} \times 3)$. The combined extracts were washed with water, dried over anhydrous $\mathrm{Na}_{2} \mathrm{SO}_{4}$, and treated with $\mathrm{CH}_{2} \mathrm{~N}_{2}$ for short time (approximately $2 \mathrm{~min}$ ). After evaporation in vacuo, the residue was purified on chromatograph on a silica gel column with hexane-ethyl acetate $(V: V=5: 1)$ to give $72 \mathrm{mg}$ of $3(0.107 \mathrm{mmol}$, $51 \%$ ) as black solid. UV-vis $\left(\mathrm{CH}_{2} \mathrm{Cl}_{2}\right) \lambda_{\max }$ (relative intensity): 410 (1.00), 506 (0.13), 536 (0.13), 608 (0.05), 666 (0.32) nm; ${ }^{1} \mathrm{H}$ NMR (400 MHz, $\left.\mathrm{CDCl}_{3}\right) \delta: 9.53$ (9.54), 9.44 (9.45), 8.5 (8.58) (each s, 3H, meso-H), 6.85 (6.83) $(\mathrm{dd}, J=13.4,3.4 \mathrm{~Hz}, 1 \mathrm{H}, 3 \mathrm{a}-\mathrm{H}), 6.20(6.16)(\mathrm{s}, 1 \mathrm{H}$, $\left.13^{2}-\mathrm{H}\right), 5.43$ (5.41) (dd, $\left.J=13.4,5.6 \mathrm{~Hz}, 1 \mathrm{H}, 3 \mathrm{~b}-\mathrm{H}\right), 4.89$ (4.88) (d, $J=13.4 \mathrm{~Hz}, 1 \mathrm{H}, 3 \mathrm{~b}-\mathrm{H}), 4.47$ (q, $J=7.0 \mathrm{~Hz}, 1 \mathrm{H}$, $18-\mathrm{H}), 4.21 \sim 4.14(\mathrm{~m}, 1 \mathrm{H}, 17-\mathrm{H}), 3.62$ (q, $J=7.6 \mathrm{~Hz}, 2 \mathrm{H}$, 8a-H), 3.89 (3.88), 3.62 (3.61), 3.60 (3.58), 3.40, 3.21 (3.20) (each s, each $\left.3 \mathrm{H}, \mathrm{CH}_{3}+\mathrm{OCH}_{3}\right), 2.65 \sim 2.48(\mathrm{~m}, 2 \mathrm{H}$, $17 \mathrm{a}+17 \mathrm{~b}-\mathrm{H}), 2.35 \sim 2.16(\mathrm{~m}, 2 \mathrm{H}, 17 \mathrm{a}+17 \mathrm{~b}-\mathrm{H}), 1.79(\mathrm{t}$, $\left.J=7.6 \mathrm{~Hz}, 3 \mathrm{H}, 8 \mathrm{a}-\mathrm{CH}_{3}\right), 1.72\left(\mathrm{~d}, J=7.2 \mathrm{~Hz}, 3 \mathrm{H}, 18-\mathrm{CH}_{3}\right)$, 0.02 (br s, $1 \mathrm{H}, \mathrm{NH}$ ), -2.02 (br s, $1 \mathrm{H}, \mathrm{NH}$ ); EI-MS $\mathrm{m} / z$ : $669.3\left(\mathrm{M}+\mathrm{H}^{+}\right)$. Anal. calcd for $\mathrm{C}_{36} \mathrm{H}_{38} \mathrm{~N}_{5} \mathrm{O}_{8}$ : C 64.66, $\mathrm{H}$ 5.73, N 10.47; found C 64.49, H 5.67, N 10.37.

\subsection{Synthesis of methyl trans-3b-nitropyropheo-} phorbide-a (4)

An anhydrous TEA (20 mL) of chlorin 3 (114 mg, 0.171 mmol) was refluxed for $5 \mathrm{~h}$. The mixture was poured into cool water and extracted with dichloromethane $(15 \mathrm{~mL} \times$ $3)$, the combined extracts were washed with water, dried over anhydrous $\mathrm{Na}_{2} \mathrm{SO}_{4}$, and treated with $\mathrm{CH}_{2} \mathrm{~N}_{2}$ for short time (approximately $2 \mathrm{~min}$ ). After removing solvent in vacuo, the residue was purified on chromatograph on a silica gel column with hexane-ethyl acetate $(V: V=4: 1)$ to give $29 \mathrm{mg} 4(0.049 \mathrm{mmol}, 29 \%)$ as black green solid. The title compound can also be prepared from MPPd as described in the literature. ${ }^{[11 \mathrm{c}]} \mathrm{UV}$-vis $\left(\mathrm{CH}_{2} \mathrm{Cl}_{2}\right) \lambda_{\max }$ (relative intensity): 383 (1.00), 428 (0.66), $523(0.13), 563$ (0.14), 702 (0.67) nm; ${ }^{1} \mathrm{H} \mathrm{NMR}\left(400 \mathrm{MHz}, \mathrm{CDCl}_{3}\right) \delta: 9.37$ $8.76,8.58$ (each s, $3 \mathrm{H}$, meso-H), $8.76(\mathrm{~d}, J=13.5 \mathrm{~Hz}, 1 \mathrm{H}$, $3 \mathrm{a}-\mathrm{H}), 7.55$ (d, $J=13.5 \mathrm{~Hz}, 1 \mathrm{H}, 3 \mathrm{~b}-\mathrm{H}), 5.30$ (d, $J=19.7$ $\left.\mathrm{Hz}, 1 \mathrm{H}, 13^{2}-\mathrm{H}\right), 5.14$ (d, $\left.J=19.7 \mathrm{~Hz}, 1 \mathrm{H}, 13^{2}-\mathrm{H}\right), 4.71 \sim$ $4.30(\mathrm{~m}, 1 \mathrm{H}, 18-\mathrm{H}), 4.51 \sim 4.19(\mathrm{~m}, 1 \mathrm{H}, 17-\mathrm{H}), 3.67,3.57$, $3.10,3.01$ (each s, each $3 \mathrm{H}, \mathrm{CH}_{3}+\mathrm{OCH}_{3}$ ), 3.51 (q, $J=7.6$ $\mathrm{Hz}, 2 \mathrm{H}, 8 \mathrm{a}-\mathrm{H}), 2.80 \sim 2.61(\mathrm{~m}, 2 \mathrm{H}, 17 \mathrm{a}+17 \mathrm{~b}-\mathrm{H}), 2.43 \sim$ $2.26(\mathrm{~m}, 2 \mathrm{H}, 17 \mathrm{a}+17 \mathrm{~b}-\mathrm{H}), 1.86(\mathrm{~d}, J=7.4 \mathrm{~Hz}, 3 \mathrm{H}$, $\left.18-\mathrm{CH}_{3}\right), 1.63$ (t, $\left.J=7.6 \mathrm{~Hz}, 3 \mathrm{H}, 8 \mathrm{a}-\mathrm{CH}_{3}\right), 0.41$ (br s, $1 \mathrm{H}$, $\mathrm{NH}),-2.49$ (br s, 1H, NH); EI-MS $m / z$ : $594.3\left(\mathrm{M}+\mathrm{H}^{+}\right)$. Anal. calcd for $\mathrm{C}_{34} \mathrm{H}_{35} \mathrm{~N}_{5} \mathrm{O}_{5}$ : C 68.79, $\mathrm{H}$ 5.94, N11.80; found C 68.91, H 6.06, N 11.69.

\subsection{Synthesis of methyl 20-nitropheophorbide-a (5)}

To a dichloromethane solution $(50 \mathrm{~mL})$ of MPa 1 (212 $\mathrm{mg}, 0.350 \mathrm{mmol}), 0.2 \mathrm{~mL}$ of concentrated nitric acid in acetic acid $(5 \mathrm{~mL})$ was added and violently stirred at $0{ }^{\circ} \mathrm{C}$ under nitrogen atmosphere for $2 \mathrm{~h}$. The mixture was poured into cool water $(50 \mathrm{~mL})$, washed with $5 \% \mathrm{NaHCO}_{3}$, extracted with dichloromethane $(20 \mathrm{~mL} \times 2)$. The combined extracts was washed with water, dried over anhydrous $\mathrm{Na}_{2} \mathrm{SO}_{4}$, and evaporated to dryness under vacuum. The residue was purified on chromatography on a silica gel column with hexane-ethyl acetate $(V: V=4: 1)$ to give $128 \mathrm{mg}$ of $5(0.196 \mathrm{mmol}, 56 \%)$ as red solid. UV-vis $\left(\mathrm{CH}_{2} \mathrm{Cl}_{2}\right) \lambda_{\max }$ (relative intensity): 412 (1.00), 476 (0.05), 510 (0.08), 542 (0.12), 624 (0.07), 680 (0.48) nm; ${ }^{1} \mathrm{H}$ NMR $\left(400 \mathrm{MHz}, \mathrm{CDCl}_{3}\right) \delta: 9.61,9.56$ (each s, 3H, meso-H), 7.87 (dd, $J=17.8,11.5 \mathrm{~Hz}, 1 \mathrm{H}, 3 \mathrm{a}-\mathrm{H}), 6.29$ (d, $J=11.6$ $\mathrm{Hz}, 1 \mathrm{H}$, cis-3b-H), $6.20\left(\mathrm{~s}, 1 \mathrm{H}, 13^{2}-\mathrm{H}\right), 6.18(\mathrm{dd}, J=17.6$, $1.1 \mathrm{~Hz}, 1 \mathrm{H}$, trans-3b-H), $4.81 \sim 4.72(\mathrm{~m}, 1 \mathrm{H}, 17-\mathrm{H}), 4.16$ (dd, $J=8.4,3.5 \mathrm{~Hz}, 1 \mathrm{H}, 17-\mathrm{H}), 3.91,3.68,3.53,3.19,3.17$ (each s, each $3 \mathrm{H}, \mathrm{CH}_{3}+\mathrm{OCH}_{3}$ ), 3.62 (q, $J=7.6 \mathrm{~Hz}, 2 \mathrm{H}$, $8 \mathrm{a}-\mathrm{H}), 2.82 \sim 2.42(\mathrm{~m}, 2 \mathrm{H}, 17 \mathrm{a}+17 \mathrm{~b}-\mathrm{H}), 2.24 \sim 2.03(\mathrm{~m}$, $2 \mathrm{H}, 17 \mathrm{a}+17 \mathrm{~b}-\mathrm{H}), 1.67\left(\mathrm{t}, J=7.6 \mathrm{~Hz}, 3 \mathrm{H}, 8 \mathrm{a}-\mathrm{CH}_{3}\right), 1.53$ (d, $\left.J=7.2 \mathrm{~Hz}, 3 \mathrm{H}, 18-\mathrm{CH}_{3}\right),-1.92($ br s, $1 \mathrm{H}, \mathrm{NH})$, -1.96 (br s, $1 \mathrm{H}, \mathrm{NH})$; EI-MS $m / z$ : $651.4\left(\mathrm{M}+\mathrm{H}^{+}\right)$. Anal.

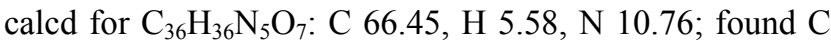
$66.51, \mathrm{H} 5.49, \mathrm{~N} 10.63$.

\subsection{Synthesis of 20-nitropurpurin-18 methyl ester (6)}

To a THF solution $(25 \mathrm{~mL})$ of chlorin $5(107 \mathrm{mg}, 0.164$ $\mathrm{mmol})$, an aqueous solution $(5 \mathrm{~mL})$ of $\mathrm{LiOH}(1.2 \mathrm{~g})$ and methanol $(15 \mathrm{~mL})$ were sequentially added. This mixture was violently stirred in open system in dark for $3 \mathrm{~h}$, poured into cool water, adjusted to $\mathrm{pH} 3$ with diluted hydrochloric acid and then extracted with dichloromethane $(25 \mathrm{~mL} \times 2)$. The combined extracts were washed with water, dried over anhydrous $\mathrm{Na}_{2} \mathrm{SO}_{4}$ and treated with $\mathrm{CH}_{2} \mathrm{~N}_{2}$ for short time (approximately $3 \mathrm{~min}$ ). After evaporation, the residue was purified on chromatography on a silica gel column with hexane-ethyl acetate $(V: V=5: 1)$ to give $73 \mathrm{mg}$ of 6 $(0.117 \mathrm{mmol}, 71 \%)$ as red solid. UV-vis $\left(\mathrm{CH}_{2} \mathrm{Cl}_{2}\right) \lambda_{\max }$ (relative intensity): 438 (1.00), 530 (0.10), $578(0.07), 656$ (0.08), 709 (0.36) nm; ${ }^{1} \mathrm{H}$ NMR (400 MHz, $\left.\mathrm{CDCl}_{3}\right) \delta$ : 9.58, 9.52 (each s, 3H, meso-H), 7.82 (dd, $J=17.8,11.6$ $\mathrm{Hz}, 1 \mathrm{H}, 3 \mathrm{a}-\mathrm{H}), 6.27$ (dd, $J=11.6 \mathrm{~Hz}, 1.41 \mathrm{H}$, cis-3b-H), $6.13(\mathrm{dd}, J=17.8,1.4 \mathrm{~Hz}, 1 \mathrm{H}$, trans-3b-H), 5.20 (dd, $J=$ 9.2, $2.6 \mathrm{~Hz}, 1 \mathrm{H}, 17-\mathrm{H}), 4.81$ (q, $J=7.2 \mathrm{~Hz}, 1 \mathrm{H}, 18-\mathrm{H}$ ), $3.78,3.58,3.50,3.16$ (each s, each $\left.3 \mathrm{H}, \mathrm{CH}_{3}+\mathrm{OCH}_{3}\right), 3.62$ $(\mathrm{q}, J=7.6 \mathrm{~Hz}, 2 \mathrm{H}, 8 \mathrm{a}-\mathrm{H}), 2.82 \sim 2.72(\mathrm{~m}, 1 \mathrm{H}, 17 \mathrm{a}+$ $17 \mathrm{~b}-\mathrm{H}), 2.42 \sim 2.28(\mathrm{~m}, 1 \mathrm{H}, 17 \mathrm{a}+17 \mathrm{~b}-\mathrm{H}), 2.06 \sim 192(\mathrm{~m}$, 
$2 \mathrm{H}, 17 \mathrm{a}+17 \mathrm{~b}-\mathrm{H}), 1.66\left(\mathrm{t}, J=7.6 \mathrm{~Hz}, 3 \mathrm{H}, 8 \mathrm{a}-\mathrm{CH}_{3}\right), 1.55$ (d, $\left.J=7.2 \mathrm{~Hz}, 3 \mathrm{H}, 18-\mathrm{CH}_{3}\right),-0.11$ (br s, $\left.1 \mathrm{H}, \mathrm{NH}\right)$, -1.53 (br s, $1 \mathrm{H}, \mathrm{NH})$; EI-MS m/z: $624.3\left(\mathrm{M}+\mathrm{H}^{+}\right)$. Anal. calcd for $\mathrm{C}_{34} \mathrm{H}_{33} \mathrm{~N}_{5} \mathrm{O}_{7}$ : C 65.48, H 5.33, N 11.23; found $\mathrm{C}$ 65.51, H 5.44, N11.19.

4.7 Synthesis of $(E / Z)-15 a-p$-nitrophenylidenechlorin- $p_{6}$ trimethyl ester $(7)$ and methy $13^{2}(E / Z)-13^{2}-p$ ntrophenylidenepyropheophorbide-a (8)

MPa 1 (208 mg, $0.343 \mathrm{mmol}$ ) and 1-(4-nitrophenyl)2-nitroethene $(136 \mathrm{mg}, 0.701 \mathrm{mmol})$ were dissolved in THF $(20 \mathrm{~mL})$, and a solution of sodium methoxide in methanol $(1 \mathrm{~mol} / \mathrm{L}, 4 \mathrm{~mL})$ was added, then the reaction mixture was stirring at room temperature under $\mathrm{N}_{2}$ atmosphere for $5 \mathrm{~h}$. The $\mathrm{pH}$ value of the reaction mixture was adjusted to $4 \sim 5$ by adding diluted hydrochloric acid, then extracted with dichloromethane. The combined organic layers were washed with water, dried over $\mathrm{Na}_{2} \mathrm{SO}_{4}$, and evaporated in vacuo. The residue was separated on silica gel column with hexane-ethyl acetate $(V: V=5: 1)$ to give $82 \mathrm{mg}$ of $7(0.107 \mathrm{mmol}, 31 \%)$ as dark green solid and $7 \mathrm{mg}$ of $\mathbf{8}(0.010 \mathrm{mmol}, 3 \%)$ as dark green solid.

7: UV-vis $\left(\mathrm{CH}_{2} \mathrm{Cl}_{2}\right) \lambda_{\max }$ (relative intensity): 413 (1.00), 502 (0.07), 531 (0.06), 611 (0.05), 664 (0.21) nm; ${ }^{1} \mathrm{H}$ NMR $\left(400 \mathrm{MHz}, \mathrm{CDCl}_{3}\right) \delta: 9.69,9.55$ (9.65), 8.70 (8.79) (each s, $3 \mathrm{H}$, meso-H), 8.63 (s, 1H, 15a-CHAr), 7.99 (7.84) (dd, $J=$ 18.0, $12.0 \mathrm{~Hz}, 1 \mathrm{H}, 3 \mathrm{a}-\mathrm{H}), 7.68$ (7.39) (d, $J=8.4 \mathrm{~Hz}, 2 \mathrm{H}$, $\mathrm{Ph}-\mathrm{H}), 7.31$ (6.47) (d, $J=8.4 \mathrm{~Hz}, 2 \mathrm{H}, \mathrm{Ph}-\mathrm{H}), 6.29$ (6.31) (d, $J=18.0 \mathrm{~Hz}, 1.41 \mathrm{H}$, trans $-3 \mathrm{~b}-\mathrm{H}), 6.10$ (6.11) (d, $J=$ $12.0 \mathrm{~Hz}, 1 \mathrm{H}$, cis-3b-H), 4.44 (q, $J=7.2 \mathrm{~Hz}, 1 \mathrm{H}, 18-\mathrm{H})$, $4.01(\mathrm{~d}, J=8.0 \mathrm{~Hz}, 1 \mathrm{H}, 17-\mathrm{H}), 3.73$ (q, $J=7.6 \mathrm{~Hz}, 2 \mathrm{H}$, 8a-H), 4.06 (3.89) 3.75, 3.55, 3.51 (3.45), 3.39 (3.43), 3.25 (3.29) (each s, each $\left.3 \mathrm{H}, \mathrm{CH}_{3}+\mathrm{OCH}_{3}\right), 2.18 \sim 2.05(\mathrm{~m}, 2 \mathrm{H}$, $17 \mathrm{a}+17 \mathrm{~b}-\mathrm{H}), 1.88 \sim 1.55(\mathrm{~m}, 2 \mathrm{H}, 17 \mathrm{a}+17 \mathrm{~b}-\mathrm{H}), 1.69(\mathrm{t}$, $\left.J=7.6 \mathrm{~Hz}, 3 \mathrm{H}, 8 \mathrm{a}-\mathrm{CH}_{3}\right), 1.01\left(\mathrm{~d}, J=7.2 \mathrm{~Hz}, 3 \mathrm{H}, 18-\mathrm{CH}_{3}\right)$, 0.62 (br s, $1 \mathrm{H}, \mathrm{NH}$ ), -1.47 (br s, $1 \mathrm{H}, \mathrm{NH}$ ); EI-MS $m / z$ : $772.5\left(\mathrm{M}+\mathrm{H}^{+}\right)$. Anal. calcd for $\mathrm{C}_{44} \mathrm{H}_{45} \mathrm{~N}_{5} \mathrm{O}_{8}$ : C 68.47, $\mathrm{H}$ 5.88, N 9.07; found C 68.56, H 6.01, N 9.19; 8: UV-vis $\left(\mathrm{CH}_{2} \mathrm{Cl}_{2}\right) \lambda_{\max }$ (relative intensity): 417 (1.00), 530 (0.19), 572 (0.17), 619 (0.19), 677 (0.83) nm; ${ }^{1} \mathrm{H}$ NMR (400 MHz, $\left.\mathrm{CDCl}_{3}\right) \delta: 9.50$ (9.56), 9.40 (9.38), 8.73 (8.58) (each s, 3H, meso-H), 8.19 (8.10) (s, 1H, 132 -CHAr), 7.98 (7.96) (dd, $J=17.6,11.2 \mathrm{~Hz}, 1 \mathrm{H}, 3 \mathrm{a}-\mathrm{H}), 8.13(7.65)(\mathrm{d}, J=8.4 \mathrm{~Hz}$, 2H, Ph-H), 7.57 (7.45) (d, $J=8.4 \mathrm{~Hz}, 2 \mathrm{H}, \mathrm{Ph}-\mathrm{H}), 6.30$ (6.28) (d, $J=17.6 \mathrm{~Hz}, 1.4 \mathrm{1H}$, trans-3b-H), 6.18 (6.17) (d, $J=11.6 \mathrm{~Hz}, 1 \mathrm{H}$, cis-3b-H), 4.90 (4.02) (d, $J=8.4 \mathrm{~Hz}, 1 \mathrm{H}$, $17-\mathrm{H}), 4.59$ (4.32) (q, $J=7.2 \mathrm{~Hz}, 1 \mathrm{H}, 18-\mathrm{H}), 3.63$ (q, $J=$ $7.6 \mathrm{~Hz}, 2 \mathrm{H}, 8 \mathrm{a}-\mathrm{H}), 3.66$ (3.76), 3.62 (3.44), 3.45 (3.40), 3.20 (each s, each $\left.3 \mathrm{H}, \mathrm{CH}_{3}+\mathrm{OCH}_{3}\right), 2.83 \sim 2.66(\mathrm{~m}, 2 \mathrm{H}$, $17 \mathrm{a}+17 \mathrm{~b}-\mathrm{H}), 2.35 \sim 2.44(\mathrm{~m}, 1 \mathrm{H}, 17 \mathrm{a}+17 \mathrm{~b}-\mathrm{H}), 2.12-2.00$ $(\mathrm{m}, 1 \mathrm{H}, 17 \mathrm{a}+17 \mathrm{~b}-\mathrm{H}), 1.95(1.82)(\mathrm{d}, J=7.2 \mathrm{~Hz}, 3 \mathrm{H}$, $\left.18-\mathrm{CH}_{3}\right), 1.68(1.70)\left(\mathrm{t}, J=7.6 \mathrm{~Hz}, 3 \mathrm{H}, 8 \mathrm{a}-\mathrm{CH}_{3}\right),-0.25$ (br s, $1 \mathrm{H}, \mathrm{NH}$ ), -1.88 (br s, $1 \mathrm{H}, \mathrm{NH}$ ); EI-MS m/z: 682.4 $\left(\mathrm{M}+\mathrm{H}^{+}\right)$. Anal. calcd for $\mathrm{C}_{41} \mathrm{H}_{39} \mathrm{~N}_{5} \mathrm{O}_{5}: \mathrm{C} 72.23, \mathrm{H} 5.77, \mathrm{~N}$ 10.27; found C 72.31, H 5.60, N 10.24.

\subsection{Synthesis of methyl pyropheophorbide-a (9)}

MPa 1 (212 mg, $0.350 \mathrm{mmol}$ ) was dissolved in 5\% aqueous solution of pyridine $(15 \mathrm{~mL})$ and refluxed under nitrogen atmosphere for $5 \mathrm{~h}$. The resultant mixture was poured to cool water, extracted with dichloromethane (20 $\mathrm{mL} \times 2$ ). The combined organic layers were washed with water, dried over $\mathrm{Na}_{2} \mathrm{SO}_{4}$, and evaporated to dryness in vacuum. The residue was separated on silica gel column with hexane-ethyl acetate $(V: V=5: 1)$ to give $140 \mathrm{mg}$ of $9(0.256 \mathrm{mmol}, 73 \%)$ as dark green solid. The analytical data were consistent with the ones in the literature. ${ }^{[12]}$

4.9 Synthesis of methyl 12-formyl-12-demethylpyropheophorbide-a (10) and methyl $13^{2}$-oxopheopyrophorbide-a (11)

To a THF solution (25 mL) of MPPa $9(660 \mathrm{mg}, 1.203$ $\mathrm{mmol})$, an aqueous solution $(25 \mathrm{~mL})$ of $\mathrm{LiOH}(1300 \mathrm{mg})$ and methanol $(50 \mathrm{~mL})$ was sequentially added. This mixture was violently stirred in open system in dark for $3 \mathrm{~h}$, poured into cool water, adjusted $\mathrm{pH}$ to $3 \sim 4$ with $5 \%$ hydrochloric acid, and then extracted with dichloromethane $(80 \mathrm{~mL} \times 2)$. The combined extracts were washed with water, dried over anhydrous $\mathrm{Na}_{2} \mathrm{SO}_{4}$, and treated with $\mathrm{CH}_{2} \mathrm{~N}_{2}$ for short time (approximately $3 \mathrm{~min}$ ). After evaporation in vacuo, the residue was purified on chromatograph on a silica gel column with hexane-ethyl acetate $(V: V=3: 1)$ to give $142 \mathrm{mg}$ of $\mathbf{1 0}(0.253 \mathrm{mmol}, 21 \%)$ as green solid and $196 \mathrm{mg}$ of $11(0.349 \mathrm{mmol}, 29 \%)$ as yellow solid. Their analytical data were consistent with the ones in the literature. ${ }^{[14 a]}$

\subsection{Synthesis of methyl $13^{2}$-methylenepyropheo- phorbide-a (12)}

MPPa 9 (421 mg, $0.767 \mathrm{mmol}$ ) was dissolved in THF $(20 \mathrm{~mL})$ and para-formaldehyde $(400 \mathrm{mg})$ was added while stirring. To the solution was successively added a solution of sodium methoxide in methanol ( $1 \mathrm{~mol} / \mathrm{L}, 4 \mathrm{~mL})$ followed by stirring under $\mathrm{N}_{2}$ atmosphere at room temperature for $6 \mathrm{~h}$. The resulting solution was acidized with diluted $\mathrm{HCl}(40 \mathrm{~mL})$ and extracted with dichloromethane $(20$ $\mathrm{mL} \times 3)$. The organic layers were combined and concentrated in vacuo. The residue was dissolved in dichloromethane and treated with diazomethane to convert the carboxylic acid back into methyl ester. After chromatography on silica gel with hexane-ethyl acetate $(V: V=3$ : 1) as an eluent to give $323 \mathrm{mg} 12(0.576 \mathrm{mmol}, 75 \%)$ as dark yellow solid. UV-vis $\left(\mathrm{CH}_{2} \mathrm{Cl}_{2}\right) \lambda_{\text {max }}$ (relative intensity): 412 (1.00), 433 (0.86), 525 (0.11), 560 (0.08), 616 (0.08), 675 (0.49) nm; ${ }^{1} \mathrm{H}$ NMR (400 MHz, $\left.\mathrm{CDCl}_{3}\right) \delta$ : $9.58,9.47,8.71$ (each s, 3H, meso-H), 8.01 (dd, $J=17.8$, $11.6 \mathrm{~Hz}, 1 \mathrm{H}, 3 \mathrm{a}-\mathrm{H}), 6.81\left(\mathrm{~s}, 1 \mathrm{H}, 13^{2} \mathrm{a}-\mathrm{H}\right), 6.52(\mathrm{~s}, 1 \mathrm{H}$, $\left.13^{2} \mathrm{a}-\mathrm{H}\right), 6.30(\mathrm{dd}, J=17.8,1.1 \mathrm{~Hz}, 1 \mathrm{H}$, trans-3b-H), 6.18 (d, $J=11.6,1.1 \mathrm{~Hz}, 1 \mathrm{H}$, cis-3b-H), 4.65 (d, $J=9.2 \mathrm{~Hz}, 1 \mathrm{H}$, 17-H), 4.56 (q, $J=7.4 \mathrm{~Hz}, 1 \mathrm{H}, 18-\mathrm{H}), 3.68$ (q, $J=7.6 \mathrm{~Hz}$, $2 \mathrm{H}, 8 \mathrm{a}-\mathrm{H}$ ), 3.73, 3.65, 3.44, 3.23 (each s, each $3 \mathrm{H}, \mathrm{CH}_{3}+$ $\left.\mathrm{OCH}_{3}\right), 2.75 \sim 2.62(\mathrm{~m}, 2 \mathrm{H}, 17 \mathrm{a}+17 \mathrm{~b}-\mathrm{H}), 2.37 \sim 2.30(\mathrm{~m}$, $1 \mathrm{H}, 17 \mathrm{a}+17 \mathrm{~b}-\mathrm{H}), 2.10 \sim 1.98(\mathrm{~m}, 1 \mathrm{H}, 17 \mathrm{a}+17 \mathrm{~b}-\mathrm{H}), 1.85$ (d, $\left.J=7.4 \mathrm{~Hz}, 3 \mathrm{H}, 18-\mathrm{CH}_{3}\right), 1.69$ (t, $J=7.6 \mathrm{~Hz}, 3 \mathrm{H}$, $8 \mathrm{a}-\mathrm{CH}_{3}$ ), -0.11 (br s, $\left.1 \mathrm{H}, \mathrm{NH}\right),-1.97$ (br s, $\left.1 \mathrm{H}, \mathrm{NH}\right)$; EI-MS $m / z$ : $561.4\left(\mathrm{M}+\mathrm{H}^{+}\right)$. Anal. calcd for $\mathrm{C}_{35} \mathrm{H}_{36} \mathrm{~N}_{4} \mathrm{O}_{3}$ : 
C 74.98, H 6.47, N 9.99; found C 75.02, H 6.51, N 9.97.

4.11 Synthesis of methyl 12-(trans-2'-nitrovinyl)-12demethylmethylenepyropheophorbide-a (13)

Chlorin 10 (137 mg, $0.244 \mathrm{mmol}$ ) was dissolved in TEA $(5 \mathrm{~mL})$ and excess nitromethane $(3 \mathrm{~mL})$ was added while stirring followed by stirring under nitrogen atmosphere at room temperature for $4 \mathrm{~h}$. The resultant mixture was poured into cool water and extracted with dichloromethane $(15 \mathrm{~mL} \times 3)$. The combined extracts were washed with water, dried over anhydrous $\mathrm{Na}_{2} \mathrm{SO}_{4}$, and treated with $\mathrm{CH}_{2} \mathrm{~N}_{2}$ for short time (approximately $3 \mathrm{~min}$ ). After evaporation in vacuo, the residue was purified on chromatograph on a silica gel column with hexane-ethyl acetate $(V: V=4: 1)$ to give $67 \mathrm{mg}$ of $13(0.110 \mathrm{mmol}, 45 \%)$ as black solid. UV-vis $\left(\mathrm{CH}_{2} \mathrm{Cl}_{2}\right) \lambda_{\max }$ (relative intensity): 407 (1.00), 600 (0.20), 660 (0.26), 704 (0.33) nm; ${ }^{1} \mathrm{H}$ NMR $\left(400 \mathrm{MHz}, \mathrm{CDCl}_{3}\right) \delta: 9.07(\mathrm{~d}, J=12.9 \mathrm{~Hz}, 1 \mathrm{H}, 12 \mathrm{a}-\mathrm{H})$, $8.76,8.53,8.19$ (each s, 3H, meso-H), 7.77 (dd, $J=17.8$, $11.6 \mathrm{~Hz}, 1 \mathrm{H}, 3 \mathrm{a}-\mathrm{H}), 7.55$ (d, $J=12.9 \mathrm{~Hz}, 1 \mathrm{H}, 12 \mathrm{~b}-\mathrm{H}), 6.23$ (d, $J=17.8 \mathrm{~Hz}, 1 \mathrm{H}$, trans $-3 \mathrm{~b}-\mathrm{H}), 6.17$ (d, $J=11.6 \mathrm{~Hz}, 1 \mathrm{H}$, cis-3b-H), 4.99 (d, $\left.J=19.7 \mathrm{~Hz}, 1 \mathrm{H}, 13^{2}-\mathrm{H}\right), 4.83$ (d, $J=$ $19.7 \mathrm{~Hz}, 1 \mathrm{H}, 13^{2}-\mathrm{H}$ ), 4.26 (q, $J=7.0 \mathrm{~Hz}, 1 \mathrm{H}, 18-\mathrm{H}$ ), 4.05 (d, $J=9.6 \mathrm{~Hz}, 1 \mathrm{H}, 17-\mathrm{H}), 3.27$ (q, $J=7.6 \mathrm{~Hz}, 2 \mathrm{H}, 8 \mathrm{a}-\mathrm{H})$, 3.66, 3.25, 2.98 (each s, each $3 \mathrm{H}, \mathrm{CH}_{3}+\mathrm{OCH}_{3}$ ), 2.64 $2.52(\mathrm{~m}, 1 \mathrm{H}, 17 \mathrm{a}+17 \mathrm{~b}-\mathrm{H}), 2.40 \sim 2.32(\mathrm{~m}, 1 \mathrm{H}, 17 \mathrm{a}+$ $17 \mathrm{~b}-\mathrm{H}), 2.23 \sim 2.03(\mathrm{~m}, 2 \mathrm{H}, 17 \mathrm{a}+17 \mathrm{~b}-\mathrm{H}), 1.81(\mathrm{~d}, J=7.2$ $\left.\mathrm{Hz}, 3 \mathrm{H}, 18-\mathrm{CH}_{3}\right), 1.47$ (t, J=7.6 Hz, 3H, 8a-CH ), 0.07 (br $\mathrm{s}, 1 \mathrm{H}, \mathrm{NH}),-0.11($ br s, $1 \mathrm{H}, \mathrm{NH})$. Anal. calcd for $\mathrm{C}_{35} \mathrm{H}_{35} \mathrm{~N}_{5} \mathrm{O}_{5}$ : C 69.41, H 5.82, N 11.56; found $\mathrm{C} 69.53, \mathrm{H}$ 5.90, N 11.51.

4.12 Synthesis of methyl $13^{1}$-(trans-2'-nitromethylene)-13 ${ }^{1}$-deoxo-13 ${ }^{2}$-oxopyropheophorbide-a (14)

Chlorin 11 (143 mg, $0.254 \mathrm{mmol}$ ) was dissolved in TEA $(5 \mathrm{~mL})$ and excess nitromethane $(3 \mathrm{~mL})$ was added while stirring followed by refluxing under nitrogen atmosphere at room temperature for $3 \mathrm{~h}$. The resultant mixture was poured into cool water and extracted with dichloromethane $(15 \mathrm{~mL} \times 3)$. The combined extracts were washed with water, dried over anhydrous $\mathrm{Na}_{2} \mathrm{SO}_{4}$, and treated with $\mathrm{CH}_{2} \mathrm{~N}_{2}$ for short time (approximately $3 \mathrm{~min}$ ). After evaporation in vacuo, the residue was purified on chromatograph on a silica gel column with hexane-ethyl acetate $(V: V=$ $4: 1)$ to give $52 \mathrm{mg} 14(0.086 \mathrm{mmol}, 34 \%)$ as black solid. UV-vis $\left(\mathrm{CH}_{2} \mathrm{Cl}_{2}\right) \lambda_{\max }$ (relative intensity): 397 (1.00), 697 (0.33) nm; ${ }^{1} \mathrm{H}$ NMR (400 MHz, $\left.\mathrm{CDCl}_{3}\right) \delta$ : 9.68, 8.91, 8.16 (each s, 3H, meso-H), $9.50\left(\mathrm{~s}, 1 \mathrm{H}, 13^{2} \mathrm{a}-\mathrm{H}\right), 8.03$ (dd, $J=$ 17.8, $11.6 \mathrm{~Hz}, 1 \mathrm{H}, 3 \mathrm{a}-\mathrm{H}), 6.30(\mathrm{~d}, J=17.8 \mathrm{~Hz}, 1 \mathrm{H}$, trans-3b-H), $6.21(\mathrm{~d}, J=11.6 \mathrm{~Hz}, 1 \mathrm{H}$, cis-3b-H), $5.10(\mathrm{~d}$, $J=9.6 \mathrm{~Hz}, 1 \mathrm{H}, 17-\mathrm{H}), 4.62$ (q, $J=7.2 \mathrm{~Hz}, 1 \mathrm{H}, 18-\mathrm{H}), 3.60$ (q, $J=7.6 \mathrm{~Hz}, 2 \mathrm{H}, 8 \mathrm{a}-\mathrm{H}), 3.60,3.56,3.47,3.22$ (each s, each $\left.3 \mathrm{H}, \mathrm{CH}_{3}+\mathrm{OCH}_{3}\right), 2.83 \sim 2.65(\mathrm{~m}, 2 \mathrm{H}, 17 \mathrm{a}+17 \mathrm{~b}-\mathrm{H})$, $2.42 \sim 2.27(\mathrm{~m}, 1 \mathrm{H}, 17 \mathrm{a}+17 \mathrm{~b}-\mathrm{H}), 2.10 \sim 1.99(\mathrm{~m}, 1 \mathrm{H}, 17 \mathrm{a}$ $+17 \mathrm{~b}-\mathrm{H}), 1.87\left(\mathrm{~d}, J=7.2 \mathrm{~Hz}, 3 \mathrm{H}, 18-\mathrm{CH}_{3}\right), 1.64(\mathrm{t}, J=7.6$ $\mathrm{Hz}, 3 \mathrm{H}, 8 \mathrm{a}-\mathrm{CH}_{3}$ ), 0.15 (br s, $1 \mathrm{H}, \mathrm{NH}$ ), -2.18 (br s, $1 \mathrm{H}$, $\mathrm{NH})$; EI-MS $m / z$ : $606.4\left(\mathrm{M}+\mathrm{H}^{+}\right)$. Anal. calcd for $\mathrm{cC}_{35} \mathrm{H}_{35} \mathrm{~N}_{5} \mathrm{O}_{5}$ : C 69.41, H 5.82, N 11.56; found $\mathrm{C} 69.39, \mathrm{H}$
5.77, N 11.39.

4.13 Synthesis of methyl $13^{2}(R / S)-13^{2}-\left(2^{\prime}\right.$-nitroethyl)pyropheophorbide-a (15)

Chlorin 12 (182 mg, $0.325 \mathrm{mmol})$ and excess nitromethane $(5 \mathrm{~mL})$ were dissolved in THF $(15 \mathrm{~mL})$, after a solution of sodium methoxide in methanol $(1 \mathrm{~mol} / \mathrm{L}, 4 \mathrm{~mL})$ was added. The resultant reaction mixture was stirring at $35{ }^{\circ} \mathrm{C}$ under $\mathrm{N}_{2}$ atmosphere for $2 \mathrm{~h}$, poured to cool water and extracted with dichloromethane $(15 \mathrm{~mL} \times 3)$. The combined organic layers were washed with water, dried over $\mathrm{Na}_{2} \mathrm{SO}_{4}$, and evaporated in vacuo. The residue was separated on silica gel column with hexane-ethyl acetate $(V: V=4: 1)$ to give $117 \mathrm{mg}$ of $15(0.188 \mathrm{mmol}, 58 \%)$ as black solid. UV-vis $\left(\mathrm{CH}_{2} \mathrm{Cl}_{2}\right) \lambda_{\max }$ (relative intensity): 412 (2.769), 508 (0.085), 538 (0.068), 610 (0.064), 668 (0.342) $\mathrm{nm} ;{ }^{1} \mathrm{H}$ NMR $\left(400 \mathrm{MHz}, \mathrm{CDCl}_{3}\right) \delta: 9.20$ (9.18), 8.92 (8.90), 8.47 (each s, 3H, meso-H), $7.63(\mathrm{dd}, J=17.6,11, .2$ $\mathrm{Hz}, 1 \mathrm{H}, 3 \mathrm{a}-\mathrm{H}), 6.04$ (d, $J=18.6 \mathrm{~Hz}, 1 \mathrm{H}$, trans-3b-H), 5.95 $(\mathrm{d}, J=11.2 \mathrm{~Hz}, 1 \mathrm{H}$, cis-3b-H), $5.41(\mathrm{~d}, J=6.8 \mathrm{~Hz}, 1 \mathrm{H}$, $\left.13^{2}-\mathrm{H}\right), 4.95$ (4.94) (q, $\left.J=7.2 \mathrm{~Hz}, 1 \mathrm{H}, 18-\mathrm{H}\right), 4.69 \sim 4.59$ (m, 1H, 17-H), 4.38 (d, J=6.8 Hz, 1H, 13² b-H), 4.37 (d, $\left.J=6.0 \mathrm{~Hz}, 1 \mathrm{H}, 13^{2} \mathrm{~b}-\mathrm{H}\right), 3.32$ (q, $\left.J=7.2 \mathrm{~Hz}, 2 \mathrm{H}, 8 \mathrm{a}-\mathrm{H}\right)$, 3.63, 3.57, 3.22, 2.87 (2.86) (each s, each $3 \mathrm{H}, \mathrm{CH}_{3}+$ $\left.\mathrm{OCH}_{3}\right), 3.48 \sim 3.65\left(\mathrm{~m}, 1 \mathrm{H}, 13^{2} \mathrm{a}-\mathrm{H}\right), 3.26 \sim 3.10(\mathrm{~m}, 1 \mathrm{H}$, $\left.13^{2} \mathrm{a}-\mathrm{H}\right), 2.62 \sim 2.50(\mathrm{~m}, 1 \mathrm{H}, 17 \mathrm{a}+17 \mathrm{~b}-\mathrm{H}), 2.27 \sim 2.18(\mathrm{~m}$, $1 \mathrm{H}, 17 \mathrm{a}+17 \mathrm{~b}-\mathrm{H}), 2.00 \sim 1.89(\mathrm{~m}, 2 \mathrm{H}, 17 \mathrm{a}+17 \mathrm{~b}-\mathrm{H}), 1.89$ $\left(\mathrm{d}, J=6.8 \mathrm{~Hz}, 3 \mathrm{H}, 18-\mathrm{CH}_{3}\right), 1.52(\mathrm{t}, J=7.2 \mathrm{~Hz}, 3 \mathrm{H}$, $\left.8 \mathrm{a}-\mathrm{CH}_{3}\right), 0.28$ (br s, $\left.1 \mathrm{H}, \mathrm{NH}\right),-1.82$ (br s, $\left.1 \mathrm{H}, \mathrm{NH}\right)$; EI-MS $m / z$ : $622.3\left(\mathrm{M}+\mathrm{H}^{+}\right)$. Anal. calcd for $\mathrm{C}_{36} \mathrm{H}_{39} \mathrm{~N}_{5} \mathrm{O}_{6}$ : C 69.55, H 6.32, N 11.26; found C 69.67, H 6.42, N 11.31.

Supporting Information ${ }^{1} \mathrm{H}$ NMR spectra of the new compounds. The Supporting Information is available free of charge via the Internet at http://sioc-journal.cn.

\section{References}

[1] (a) Ali, H.; Vanlier, J. E. In Handbook of Porphyrin Science, Vol. 4, Eds.: Kadish, K. M.; Smith, K. M.; Guilard, R., World Scientific Publishing Company, Singapore, 2010, p. 1

(b) Ethirajan, M.; Patel, N. J.; Pandey, R. K. In Handbook of Porphyrin Science, Vol. 4, Eds.: Kadish, K. M.; Smith, K. M.; Guilard, R., World Scientific Publishing Company, Singapore, 2010, p. 249. (c) Gil, M.; Bieniaszl, M.; Seshadri, M.; Fisher, D.; Ciesielski, M. J.; Chen, Y.; Pandey, R. K.; Kozbor, D. Brit. J. Cancer. 2011, 103(10), 1

[2] (a) Pandey, S. K.; Zheng, X.; Morgan, J.; Missert, J. R.; Liu, T.-H.; Shibata, M.; Bellnier, D. A.; Oseroff, A. R.; Henderson, B. W.; Dougherty, T. J.; Pandey, R. K. Mol. Pharm. 2007, 4, 448.

(b) Li, J.; He, N.; Liu, Y.; Zhang, Z.; Zhang, X.; Han, X.; Gai, Y.; Liu, Y.; Yin, J.; Wang, J. Dyes Pigm. 2017, 146, 189.

(c) Jiang, Q.-Y.; Zhang, Z.; Liu, Y.; Yao, N.-N.; Wang, J.-J. Chin. J. Org. Chem. 2017, 37, 1814 (in Chinese).

(姜齐永, 张珠, 刘洋, 姚楠楠, 王进军, 有机化学, 2017, 37, 1814.)

[3] (a) Wang, J.-J. Chin. J. Org. Chem. 2005, 25, 1353 (in Chinese). (王进军, 有机化学, 2005, 25, 1353.)

(b) Ethirajan, M.; Joshi, P.; William, W. H.; Ohkubo, K.; Fukuzumi, S.; Pandey, R. K. Org. Lett. 2011, 8, 1956.

(c) Bellnier, D. A.; Greco, W. R.; Loewen, G. M.; Nava, H.; Oseroff, A. R.; Pandey, R. K.; Tsuchida, T.; Dougherty, T. J. Can- 
cer. Res. 2003, 63, 1806.

[4] (a) Ethirajan, M.; Chen, P.; Ohulchanskyy, T. Y.; Goswami, L. N.; Gupta, A.; Srivatsan, A.; Dobhal, M. P.; Missert, J. R.; Prasad, P. N.; Kadish, K. M. Chem. Eur. J. 2013, 19, 6670.

(b) Pandey, R. K.; Goswami, L. N.; Chen, Y.; Gryshuk, A.; Missert, J. R.; Oseroff, A.; Dougherty, T. J. Lasers Surg. Med. 2006, 467, 445.

(c) Tamiaki, H.; Wada, A.; Matsubara, S. J. Photochem. Photobiol. A: Chem. 2018, 353, 581.

[5] (a) Pandey, S. K.; Zheng, X.; Morgan, J.; Missert, J. R.; Liu, T.-H.; Shibata, M.; Bellnier, D. A.; Oseroff, A. R.; Henderson, B. W.; Dougherty, T. J.; Pandey, R. K. Mol. Pharm. 2007, 4, 448.

(b) Kozyrey, A. N.; Chen, Y.-H.; Goswami, L. N.; Tabaczynaki, W. A.; Pandey, R. K. J. Org. Chem. 2006, 71, 1949.

(c) Duan, S.; Dall'Agnese, C.; Chen, G.; Wang, X.-F.; Tamiaki, H.; Yamamoto, Y.; Ikeuchi, T.; Sasaki, S. ACS Energy Lett. 2018, 3, 1708.

[6] (a) Wang, L.-M.; Wang, Z.; Yang, Z.; Jin, Y.-X.; Wang, J.-J. Chin. J. Org. Chem. 2012, 32, 2154 (in Chinese).

(王鲁敏, 王振, 杨泽, 金英学, 王进军, 有机化学, 2012, 32, 2154.)

(b) Liu, Y.; Xu, X.-S.; Li, J.-Z.; Yin, J.-G.; Qi, C.-X.; Wang, J.-J. Chin. J. Org. Chem. 2014, 34, 552 (in Chinese).

(刘洋, 徐希森, 李家柱, 殷军港, 祁彩霞, 王进军, 有机化学, 2014, 34, 552.)

(c) Gao, N.; Li, J.-Z.; Li, Y.-L.; Wang, Z.; Wang, J.-J. Chin. Chem. Lett. 2016, 27, 789.

(d) Wu, H.-Q.; Wang, X.-M.; Liu, Y.; Zhao, Y.; Shim, Y.-K.; Yoon, I.; Xu, X.-M.; Li, J.-Z. Bull. Korean Chem. Soc. 2020, 41, 504.

[7] (a) Wang, J.-J.; Wang, P.; Li, J.-Z.; Jakus, J.; Shin, Y.-K. Bull. Korean Chem. Soc. 2011, 32, 3473.

(b) Wang, L.-M.; Wang, P.; Liu, C.; Jin, Y.-X.; Wang, J.-J. Chin. J. Org. Chem. 2012, 32, 1700 (in Chinese).

(王鲁敏, 王朋, 刘超, 金英学, 王进军, 有机化学, 2012, 32, 1700.)

(c) Ji, J.-Y.; Yin, J.-G.; Zhang, Q.; Liu, C.; Qi, C.-X.; Wang, J.-J. Chin. J. Org. Chem. 2014, 34, 2047 (in Chinese).

(纪建业, 殷军港, 张千, 刘超, 祁彩霞, 王进军, 有机化学, 2014, 34, 2047.)

(d) Shoji, S.; Nomura, Y.; Tamiaki, H. Tetrahedron 2020, 76, 131130 .

[8] (a) Li, J.-Z.; Zhang, P.; Yao, N.-N.; Zhao, L.-L.; Wang, J.-J.; Shim, Y.-K. Tetrahedron Lett. 2014, 55, 1086.

(b) Liu, Y.; Wu, H.; Zhang, X.; Pan, Q.; Wang, X.-M.; Peng, W.; Yin, J.-G.; Li, G.-Z.; Li, J.-Z.; Wang, J.-J. Chem. Pap. 2018, 72, 1389 . (c) Wang, J.-J.; Li, J.-Z.; Jakus. J.; Shim, Y. K. J. Porphyrins Phthalocyanines 2012, 16, 122.

(d) Takahashi, T.; Ogasawara, S.; Shinozaki, Y.; Tamiaki, H. Bull. Chem. Soc. Jpn. 2020, 93, 467.

(e) Zhang, Z.; Xu, X.; Li, Y.; Li, J.; Wang, J. Chin. J. Org. Chem. 2018, 38, 2993 (in Chinese).

(张珠, 徐希森, 李彦龙, 李家柱, 王进军, 有机化学, 2018, 38, 2993.)

[9] (a) Silva, A. M. G.; Tomé, A. C.; Neves, M. G. P. M. S.; Cavaleiro, J. A. S. Synlett 2002, 1155.

(b) Richeter, S. B.; Jeandon, C.; Gisselbrecht, J.-P.; Graff, R.; Ruppert, R.; Callot, H. J. Inorg. Chem. 2004, 43, 251.

[10] (a) Richeter, S.; Hadj-aissa, A.; Taffin, C.; van der Lee, A.; Leclercq, D. Chem. Commun. 2007, 2148.

(b) Mandoj, F.; Nardis, S.; Pudi, R.; Lvova, L.; Fronczek, F. R.; Smith, K. M.; Prodi, L.; Genovese, D.; Paolesse, R. Dyes Pigm. 2013, 99, 136

[11] (a) Xu, X.-S.; Yao, N.-N.; Liu, Y.; Yin, J.-G.; Qi, C.-X.; Wang, J.-J. Chin. J. Org. Chem. 2014, 34, 938 (in Chinese).

(徐希森, 姚楠楠, 刘洋, 殷军港, 祁彩霞, 王进军, 有机化学, 2014, 34, 938.)

(b) Wang, Z.; Yang, Z.; Liu, Y.; Xu, X.-S.; Qi, C.-X.; Wang, J.-J. Chin. J. Org. Chem. 2012, 32, 2300 (in Chinese). (王振, 杨泽, 刘洋, 徐希森, 祁彩霞, 王进军, 有机化学, 2012, 32,2300 .)

(c) Tamiaki, H.; Ohata, M.; Kinoshita, Y.; Machida, S. Tetrahedron 2014, 70, 1629.

[12] Smith, K. M.; Gogg, D. A.; Simpson, D. J. J. Am. Chem. Soc. 1985, 107, 4946.

[13] (a) Doyle, A. G.; Jacobsen, E. N. J. Am. Chem. Soc. 2007, 107, 5713.

(b) Shi. M.; Chen, L.-H.; Li, C.-J. Chem. Rev, 2005, 127, 3790.

(c) Inokuma, T.; Hoashi, Y.; Takemoto, Y. J. Am. Chem. Soc, 2006, $128,9413$.

(d) Jung, C. K.; KrisChe, M. J. J. Am. Chem. Soc, 2006, 128, 17051.

[14] (a) Li, J.-Z.; Cui, B.-C.; Wang, J.-J.; Shim, Y.-K. Bull. Korean Chem. Soc. 2011, 32, 2465.

(b) Zhang, S.-G. M.S. Thesis, Yantai University, Yantai, 2015 (in Chinese).

(张善国, 硕士论文, 烟台大学, 烟台, 2015.)

[15] Kureishi, Y.; Tamiaki, H. J. Porphyrins Phthalocyanines 1998, 2, 159.

[16] Han, G.-F.; Wang, J.-J.; Qu, Y.; Shim, Y.-K. Chin. J. Org. Chem. 2006, 26, 43 (in Chinese).

(韩光范, 王进军, 翟燕, 沈荣基, 有机化学, 2006, 26, 43.)

(Li, L.; Fan, Y.) 